\title{
Lived Experiences of Women of Color in Education
}

\author{
Noni Mendoza-Reis \\ San Jose State University \\ noni.mendozareis@sjsu.edu \\ Rosalinda Quintanar-Sarellana \\ San Jose State University \\ Rosalinda.Quintanar@sjsu.edu
}

\begin{abstract}
By building upon previous research of women of color in academia, this article focuses on the lived experiences and narratives of two faculty members. Their stories are presented as case studies which explicate the distinct difference between reading and researching poverty and having experiential knowledge of this circumstance. The first narrative presents a scholar from a farmworker background who understands and has lived in poverty. Because of this background, she is able to apply her own community cultural wealth to her work in education. The second narrative depicts a scholar with a rich academic background that did not have the opportunity to engage fully with her research agenda. Her life in academia was very rich and she was able to help many students, schools and communities. However, she was forced to set aside her dreams of conducting in depth research of the issues confronted by her underserved community.
\end{abstract}

Keywords: Women of color, academia, working class scholars, critical race theory, community cultural wealth, cultural taxation

\section{Introduction}

Ten years ago, a colleague and I conducted a study about the experiences of women of color in higher education (Mendoza-Reis \& Lu, 2010). The research topic was derived from our lived experiences as faculty of color in predominantly white institutions. We faced some challenges in this study. The first challenge was the absence of existing literature in the field. Although there was a body of knowledge on female faculty in academia, missing were the voices of women faculty of color (WFC). The second challenge was in identifying the faculty at our institution. We had hoped to recruit tenure or tenure-track WFC as participants. We expanded our selection criteria to add part-time faculty as participants due to the scarcity of tenure and tenure-track WFC at our institution.

Using Critical Race Theory as our conceptual framework, we gathered counter stories of the lived experiences of WFC. Daniel Solorazano $(1997,1998)$ defined five tenets of critical race theory that include: (1) the intercentricity of race and racism; (2) the challenge to dominant ideology; (3) the commitment to social justice; (4) the centrality of experiential knowledge; and (5) the utilization of interdisciplinary approaches. Tenet four respects the experiences of people of color as "counter stories" from marginalized groups that are often ignored in traditional research methods. The counter stories we gathered from participants were centered around

Cultural and Pedagogical Inquiry, Summer 2020, 12(1), pp. 84-90

ISSN 1916-3460 @ 2020 University of Alberta

http://ejournals.library.ualberta.ca/index.php/cpi/index 
themes of competence, confidence and credibility that were consistent with the relevant literature (Berry \& Mizelle, 2006; Ladsen-Billings, 1996; Stanley, 2006; Turner, 2006). The counter stories reflected marginalization, double and triple oppression and a sense of tokenism. All of the faculty who participated in this study reported that they had to work twice as hard to be perceived as credible and not inefficient. This meant taking on extra workloads including serving on more than the required committees and completing tasks to perfection without any recognition being given to the additional time spent. As importantly, faculty reported surviving by creating "niches" at the local, state and national levels where they were recognized in ways that their home campuses failed to do. All participants reported experiencing a sense of competence, confidence and credibility but that it had taken many years to accomplish.

Ten years later, the imbalance in number of WFC in the professoriate persists. Indeed, were we to replicate this study today we might be faced with similar challenges as the ones identified in our earlier study. In the study, "Why are there so few of us", we reported 2005 data from the Chronicle of Higher Education which stated that $35 \%$ of tenure track faculty (assistant, associate and full professors) in all academic fields were female and 5\% were women of color. The persistent imbalance in racial and ethnic diversity among faculty in the U.S. continues. In a 2017 report by the National Center for Education Statistics (NCES) there were 1.5 million faculty in higher education. However, when the data is disaggregated by gender, race and ethnicity, the imbalance is more revealing:

For example, among full-time professors, 54 percent were White males, 27 percent were White females, 8 percent were Asian/Pacific Islander males, and 3 percent were Asian/Pacific Islander females. Black males, Black females, and Hispanic males each accounted for 2 percent of full-time professors. The following groups each made up 1 percent or less of the total number of full-time professors: Hispanic females, American Indian/Alaska Native individuals, and individuals of two or more races. (NCES, 2017)

In the last ten years, there have been many studies addressing gender, race and ethnicity among higher education faculty. There is also a body of knowledge about faculty who intersect in terms of race and class. This article adds to the literature with two new case studies. One focuses on the community cultural wealth that women of color scholars from lower and workingclass backgrounds bring to academia. The second concentrates on cultural taxation factors encountered by ethnic scholars.

\section{Case Study 1: Noni Mendoza-Reis' Experiences in Academia}

As in the earlier study, "Why Are There So Few of Us", my case is also framed within a critical race lens. Building on critical race theory, Tara Yosso (2005) conceptualized community cultural wealth as a challenge to deficit perspectives of cultural capital. Yosso maintains that communities of color have six forms of capital that build on one another to create a community's cultural wealth. The six types of capital identified by Yosso (2005) include: aspirational, linguistic, familial, social, navigational and resistant capital. We present examples of these types of capital in the following discussion. 


\section{Reis' Experiential Knowledge Applied in K-12 Schools: Community Cultural Wealth}

Familial and social capital. When I was a teacher and school principal in a farmworker community, my background was much appreciated by students and their families. I would often share my farmworker background as a motivating factor to students and parents. My insider knowledge about farmworkers provided for a trusting relationship with both students and families. I remember when mothers would come directly from the nearby strawberry fields to attend a parent conference. They would be apologetic about their appearance until I commented that my mother wore a similar bandana when she worked in the fields. (There is a particular way to fashion the bandana as a mask that protects one's face from the dust and grime of working in the fields).

My experiential knowledge about working class families of color meant that I could draw large numbers of parents to evening meetings because of our shared experiences. It was not uncommon to have conversations about current community events, interests and familial celebrations. These conversations often led to discussions about college and career readiness for their children. The families expressed a desire that their children would get a college education, confirming the community cultural wealth tenet of aspirational capital.

Navigational and resistant capital. The insider knowledge I held about growing up in a farmworker family provided an understanding of the inequities in the educational system. I had either experienced, witnessed, and later studied the marginalization, low expectations and racism that can be part of the schooling process for many students of color from lower- or workingclass backgrounds. The following scenario describes an incident where I used my positional power as a social justice school leader to create equity space on behalf of students.

A gifted young scholar. There was a period during my tenure as an elementary school principal when all administrators were mandated by our district to meet with the local police department for the purpose of "gang prevention." In a meeting, the police department identified a student from my school as the son of a local gang member and wanted to make administrators aware of this "danger." As a social justice leader, I knew such a perception would endanger this student's educational trajectory. I met with the student's teacher and learned of his exemplary writing skills. His teacher shared that she was considering submitting one of his poems to a national anthology of student poetry. As a school leader, I knew that my responsibility to this student would be to add as many assets to his education as possible in order to navigate resistance against future deficit thinking about him. I discussed the situation with the teacher and encouraged her to submit the student's poem for publication. Moreover, I was aware that a criteria for admitting students to the district's Talented and Gifted program was a teacher's recommendation. I shared this criteria with the teacher. She immediately completed the necessary paperwork to place this student in the Talented and Gifted program. His poem was accepted in the anthology, and he became a published author. These were two assets noted in the student's files that were transferred to the middle school he would attend in the fall. To ensure that these accomplishments were recognized, I called the middle school principal and informed her about the gifted young scholar who would be attending her school in the fall. 


\section{Experiential Knowledge in Academia - Barriers and Resistance}

I left my career in K-12 education to accept a tenure-track position in a university's department of Educational Leadership. At that time, I was the only Latina faculty member in a department that had been in existence for decades. My department colleagues were all former K12 school administrators with a common vision to prepare social justice leaders. In this section, I address some barriers in academia as well as the means of resistance.

Teaching off campus $=$ scholar invisibility . My first teaching assignment was in one of our program cohorts located 60 miles from the main campus. Although, preparing social justice leaders in this remote cohort brought many teaching rewards, it also meant that most of my time was spent away from the daily academic life of the university. Hence, I was limited in my ability to engage in the academic culture. This invisibility on campus limited my full participation as a scholar. I did not build relationships with many colleagues outside of my department. I was not able to participate in most campus activities. Academic discussions with colleagues were rare, and limited to the days that I was able to be on campus.

Aspirational capital as resistance. While my remote teaching assignment interfered with the ability to fully participate in academia, the university policies of Retention, Promotion and Tenure (RTP) did not take my formal, assigned work off campus into consideration in my performance assessments. Accordingly, I was still held accountable to the university's oncampus RTP guidelines. One strategy that helped meet the RTP requirements was forming 'writing collaboratives' with colleagues in similar situations. For example, mentored by our department chair, I collaborated with two other colleagues where we developed a small research and writing agenda. We co-authored three journal articles where we rotated the order of the first author. Our aspiration was to be successful in academia and so, we supported each other through the RTP process. It was situations like these that supported me to navigate the RTP process successfully, in order to achieve full professor status in a timely manner.

Unexamined assumptions about women faculty of color - What has she done? This question emerged in discussions with colleagues about the intense scrutiny of women of color in university settings. "What has she done?" was a recurring question in examining dossiers, the interviews for new hires, and applications for research grants and committees. Usually, research conducted by women of color was dismissed as "not real research." Articles written by women of color were dismissed as "light" scholarship. "What has she done" seemed to be code for "not good enough" and implied a presumption of incompetence through the assessors unexamined assumptions and their deficit perspectives of faculty women of color (Gutierrez, Nieman, Gonzalez, \& Harris, eds., 2012).

Navigational capital as resistance. In our informal discussions as senior faculty, we shared ways we resisted these biased opinions, and how we advocated for our colleagues. Some served on committees in order to defend alternate epistemologies so that our colleagues could also be on the receiving end of research grants. Articles authored by colleagues were assigned in courses so that students would be exposed to critical literature written from different perspectives. 


\section{Community Cultural Wealth in Preparing Social Justice School Leaders}

My farmworker background was invaluable in my work with students who also came from lower and working-class backgrounds. As a first-generation scholar, I was able to mentor students with similar class backgrounds who did not always know how to navigate a university system. I would remind the department chair that all of our students were local classroom teachers. A teacher's salary was barely enough to pay the university's tuition. I would often intervene with our department chair to explain why we needed to accommodate students who had additional financial obligations and usually advocated extending enrollment fees for these students.

Most importantly, a farmworker background shaped my understanding about ways to prepare social justice leaders. In addition to a formal education, my lived experience provided practical examples about ways my students could apply the theories they were learning. I came to understand and appreciate that there is a difference between scholars who have a lived experience with poverty and those who have visited poverty through research. When one has experienced poverty, the contributions are centered in first-hand experiences. Their positionality as scholars from the poverty class provides a lens that is unique. Scholars from lower or working-class backgrounds have experienced first-hand many inequities of our school system that include assumptions of low expectations, deficit perspectives and racism.

\section{Case Study 2: Rosalinda Quintana-Sarellana's Experiences in Academia}

This case study explicates an academics challenges of serving her students and community that conflict with the demands of academic scholarship. It is a classic case study of Cultural Taxation. Rosalinda Quintana-Sarellana found herself in a difficult position which prevented her from achieving her research goals, due to an excessive university workload. This is her story:

When I started a tenure track position in an urban Teacher Education Department that offered a bilingual credential, I was the only faculty member with a Mexican background. I was also one of the few bilingual faculty members. There was another professor, but he took a break from teaching and pursued an administrative position. Equally relevant was the fact that I came from a working-class family. My father attained his education by attending the late shift - La Nocturna, starting in elementary school. He worked during the day and studied at night from elementary school all the way to Law school. He instilled in me the notion that education was a viable vehicle to achieve a certain degree of social justice in society. My family was also convinced that people with formal education had an obligation to give back to the community.

At that time, most of our teacher candidates in the Bilingual Credential Program came from rural areas, 60-80 miles away from the university. Ninety percent of them came from farmworkers' backgrounds. Most of them were working full or part time in their student teaching placement in their rural hometowns. They wanted to be part of the educational system because they knew how to teach children from a culturally and linguistically diverse background. All of them had suffered at school because their language and cultural background was deemed inferior. The candidates from these rural areas were determined to make a difference in the educational system. 
This situation posed an enormous dilemma. Who was qualified and willing to supervise them in such far-away schools? These candidates were my students in other classes and I had become their de facto, mentor. I was the most invested in their education and success. As a nontenured professor, I don't know if it would have been an option to refuse to supervise them in remote rural areas. On the other hand, I wanted to supervise their teaching and mentor them to be successful. I was a willing participant that enjoyed the mentoring and the closeness with the community but was crushed by the incredible and unsustainable university workload.

In addition to my rich cultural and linguistic background, I was also very well prepared and posed to pursue academic research. It seemed the work that I was tasked to perform in the department made academic research extremely difficult, if not impossible to achieve. Although I cherished serving and living with the community, there was a palpable tension between my academic goals and the unrealistic expectations to "coordinate" a very successful and understaffed, Bilingual Credential Program, almost single handedly. My situation was a case of cultural taxation. Amado Padilla (1994) coined the term cultural taxation:

"described as a significant dilemma for ethnic scholars because we frequently find ourselves having to respond to situations that are imposed on us by the administration, or it is assumed that we are best suited for specific tasks because of our race/ethnicity or our presumed knowledge of cultural and language differences.

Service on behalf of cultural diversity is not usually in the equation for promotion within academia. Thus, what I mean by "cultural taxation" is the obligation to show good citizenship toward the institution by serving its needs for ethnic representation on committees, or to demonstrate knowledge and commitment to a cultural group, which may even bring accolades to the institution, but which is not usually rewarded by the institution on whose behalf the service was performed." (Amado Padilla, 1994)

In my case, I was the perfect missing piece of the puzzle. My native proficiency in Spanish and my shared ethnic background made me the perfect candidate to fulfill a task that few others wanted to engage in. I also understood the importance of "opening doors" and supporting the dreams of rural teacher candidates. Yes, it was indeed rewarding! What was the price? My dreams of successfully documenting and publishing the realities that I encountered were pushed to the side. I barely survived academia but I gave up my dreams to explore and analyze social phenomena that are vital to understanding our communities. I also was not able to fully participate in the life and events of the university or engage in meaningful discourse with my colleagues. In this paper, I will not even mention the effects on personal life.

The important question is: How can we nurture ethnic scholars that fit the perfect circumstance that unfortunately, can lead to a severe workload and a severely under-rewarding system? Willingness to serve low income ethnic students should not come at the expense of academic scholarship. The system helps to perpetuate having few Chicano/Latino scholars in academia. It also perpetuates having a system that attends poorly to the needs of Chicano/Latino students in the educational system, from Kindergarten through to college. 


\section{Conclusion}

It is important to tell the stories of women faculty of color in order to gain insights into the challenges faced as these scholars negotiate their spaces in academia. The two case studies in this article described lived experiences of women of color in education in both K-12 and university settings. Using critical race theory as a conceptual framework, the tenets of community cultural wealth were used to analyze barriers and resistance presented in the narratives. Barriers included deficit perspectives of students in K-12 settings, remote university teaching assignments that resulted in overload, invisibility and inability to fully function as university faculty. In response, these scholars used their community cultural wealth as resistance pedagogy that was effective in both educational settings presented in these case studies.

\section{References}

Berry, T. R., \& Mizelle, N. D. (2006). Una lucha de fronteras (a struggle of borders) women of color in the academy: From oppression to grace. Virginia: Stylus.

Brook, H., \& Michell, D. (2010). Working-class intellectuals: (Oxy)moronic professors and educational equality (A response to Ken Oldfield, A \& A, 41, 1016-1038). Administration and Society, 42(3), 368-372.

Chronicle of Higher Education. (2005). Almanac, 52(1).

Gutierrez, G. M., Nieman, Y. F., Gonzalez, C. G., \& Harris, A. P., eds. (2012). Presumed incompetent. University Press of Colorado.

Ladson-Billings, G. (1996). Silences as weapons: Challenges of a black professor teaching white students. Theory into Practice, 35(2), 79-85.

Mendoza-Reis, N., \& Lu, M. (2010). Why are there so few of us? Counter-stories from women of color in faculty governance roles. Available from: https://scholarworks.sjsu.edu/edulead_pub/5/

National Center for Education Statistics (2017).

Padilla, A. M. (1994). Educational Researcher, Vol. 23, No. 4, pp. 24-27.

Solorzano, D. (1997). Images and words that wound: Critical race theory, racial stereotyping and teacher education. Teacher Education Quarterly, 24, 5-19.

Solorzano, D. (1998). Critical race theory, racial and gender microaggressions and the experiences of Chicana and Chicano scholars. International Journal of Qualitative Studies in Education, 11, 121-136.

Stanley, C. A. (2006). Coloring the academic landscape: Faculty of color breaking the silence in predominantly while colleges and universities. American Educational Research Journal, 43(6), 701-736.

Turner, C. (2002). Women of color in academe-Living with multiple marginality. The Journal of Higher Education, 73(1), 74-93.

Yosso, T. (2005). Whose culture has capital? A critical race theory discussion of community cultural wealth. Race, Ethnicity and Education, 8(1), 69-91.

Cultural and Pedagogical Inquiry, Summer 2020, 12(1), pp. 84-90

ISSN 1916-3460 () 2020 University of Alberta

http://ejournals.library.ualberta.ca/index.php/cpi/index 